\title{
THE LONG VIEW ON KIOBEL: A MUTED VICTORY FOR INTERNATIONAL LEGAL NORMS IN THE UNITED STATES?
}

\author{
By Marco Basile*
}

Kiobel v. Royal Dutch Petroleum Co. ${ }^{1}$ may be a Trojan horse. Observers who are sympathetic to the adjudication in U.S. courts of international legal norms — such as those against torturehave criticized the decision for limiting federal jurisdiction over human rights abuses abroad. ${ }^{2}$ Yet, despite this price, Kiobel might ultimately strengthen the foundation of international legal norms in U.S. courts. Chief Justice John Roberts's majority opinion, limiting the Alien Tort Statute (ATS) ${ }^{3}$ from reaching overseas, rested on the principle that one sovereign state should not usually apply its laws within the borders of another sovereign state, and that idea is a bedrock principle of international law. The majority avoided the connection to international law by dressing up the presumption against extraterritoriality in a foreign-policy rationale, but its argument does not square with the historical record, especially when it comes to piracy. In the

* JD/PhD Candidate, Harvard University. I would like to thank Noah Feldman for comments on a previous draft.

${ }^{1}$ Kiobel v. Royal Dutch Petroleum Co., 133 S.Ct. 1659 (2013).

2 See, e.g., Adam Liptak, Justices Bar Nigerian Human Rights Case from U.S. Courts, N.Y. TimES, Apr. 18, 2013, at A22 (describing human rights groups' disappointment with Kiobel).

${ }^{3} 28$ U.S.C. $\$ 1350$. 
long run, the presumption's application is best understood in terms of certain premises about the international legal order. Kiobel might therefore contribute to a return to earlier ways in which the role of international legal norms in the United States was long taken for granted. Thus, although Kiobel is a setback for human rights litigation, it may one day prove to be a step forward out of a murky seventy-five-year-old debate over international law in U.S. courts.

\section{The ATS and Customary International Law}

Since the 1930s, the doctrinal status of customary international law in U.S. courts has been unsettled. In 1900, the Supreme Court declared in The Paquete Habana that "[i]nternational law," referring to customary international law, "is part of our law." ${ }^{4}$ But this statement was a last gasp from a previous era, rather than a guidepost for the new century. It was still the epoch of Swift v. Tyson, ${ }^{5}$ when federal courts promulgated federal general common law and applied international legal norms by incorporating them into that common law.

During the eighteenth and early nineteenth centuries, the United States developed a maritime commerce as a neutral carrier while the world was at war on the seas. Belligerents relied on privateers in addition to navies. The federal courts' dockets filled with neutrality and prize cases, and customary international law resolved those cases. ${ }^{6}$ Then, with new technology and more centralized nation-states capable of industrial warfare, the privatization of maritime warfare ended: "pirates, prizes, and privateers . . f faded or disappeared altogether." time, Americans increasingly came to view federal general common law as something judges illegitimately made, rather than as an authoritative source of law that judges discovered. As Justice Oliver Wendell Holmes famously stated in 1917, "The common law is not a brooding omnipresence in the sky...." Two decades later in Erie Railroad Co. v. Tompkins, the Supreme Court adopted Holmes's position and overruled Swift. ${ }^{9}$ The basis for customary international law in American law went out with the bathwater.

What followed was the beginning of a "normless normalcy" in American history. ${ }^{10}$ Americans became increasingly skeptical of international law's authority. It was the postwar period, and, although it witnessed the creation of the United Nations and the adoption of the Universal Declaration of Human Rights, such international institutions and instruments emerged largely stillborn, neutered by a lack of enforcement mechanisms and restrictions, such as the domestic jurisdiction clause in the UN Charter. ${ }^{11}$ The new field of international relations

\footnotetext{
${ }^{4}$ The Paquete Habana, 175 U.S. 677, 700 (1900).

${ }^{5}$ Swift v. Tyson, 41 U.S. (16 Pet.) 1 (1842).

${ }^{6}$ See David Sloss, Judicial Foreign Policy: Lessons from the 1790s, 53 ST. LOUIS U. L.J. 145, 147 (2008).

7 David L. Sloss, Michael D. Ramsey \& William S. Dodge, Continuity and Change over Two Centuries, in INTERNATIONAL LAW IN THE U.S. SUPREME COURT: CONTINUITY AND CHANGE 589, 597 (David L. Sloss, Michael D. Ramsey \& William S. Dodge eds., 2011); see also Nicholas Parrillo, The De-privatization of American Warfare: How the U.S. Government Used, Regulated, and Ultimately Abandoned Privateering in the Nineteenth Century, 19 YALE J.L. \& HUMAN. 1 (2007).

${ }^{8}$ S. Pac. Co. v. Jensen, 244 U.S. 205, 222 (1917) (Holmes, J., dissenting).

${ }^{9}$ Erie R.R. Co. v. Tompkins, 304 U.S. 64, 79-80 (1938).

${ }^{10}$ DANiEl Patrick Moynihan, On THE LaW OF NATiOnS 120 (1990).

${ }^{11}$ See Mark Mazower, The Strange Triumph of Human Rights, 1933-1950, 47 HIST. J. 379, 393 (2004).
} 
and its commitment to realism soared and crowded out less skeptical theories of international law. ${ }^{12}$

When human rights advocates rediscovered the ATS in the late 1970s as a vehicle for suing violators of international law, ${ }^{13}$ they revived the debate over the doctrinal status of international legal norms in the United States from its slumber. Although the ATS provided a statutory basis for federal jurisdiction over torts committed against aliens in violation of international law, it also required a constitutional basis, and the only plausible candidate was the clause granting federal jurisdiction over cases "arising under . . . the Laws of the United States." ${ }^{14}$ Was international law part of "the Laws of the United States"?

No one had a good answer. Critics of the ATS argued that Erie had wiped away customary international law's legal force. ${ }^{15}$ But this view seemed inconsistent with the role of customary international law for over 150 years of American history. On the other side, Louis Henkin, the dean of international law in the United States, argued that customary international law's status as part of federal law survived Erie because it was "like federal common law," yet distinguishable from it. ${ }^{16}$ On Henkin's view, "In a real sense federal courts find international law rather than make it, as was not true when courts were applying the 'common law' . . .."17 But this position seemed unpalatable, and in Sosa v. Alvarez-Machain the Supreme Court rejected it outright. ${ }^{18}$ However, Sosa did not clarify the doctrinal uncertainty regarding customary international law's status in the United States. Although the Court rejected Henkin's position, it also chose not to adopt the alternative view that customary international law was not part of U.S. law. Instead, it merely grandfathered in the "violation of safe conducts, infringement of the rights of ambassadors, and piracy" as legitimate bases for federal jurisdiction under the ATS without explaining the constitutional grounds. ${ }^{19}$

Kiobel, too, did not resolve the nearly century-long uncertainty over the status of customary international law in the United States. Unlike Sosa, Kiobel did not even address the issue. But the Court may have ultimately commented on the status of customary international law in the United States more than it had intended-or even realized.

\section{Kiobel and International Legal Order}

Kiobel held that the ATS does not generally apply to violations of international law committed outside the United States. ${ }^{20}$ Roberts's majority opinion reasoned that, absent a clear statement from the Congress to the contrary, federal courts should not apply U.S. laws to conduct that does not forcefully "touch and concern the territory of the United States." ${ }^{11}$ But from where does the aversion to extraterritoriality originate?

\footnotetext{
12 See Martti Koskenniemi, The Gentle Civilizer of Nations: The Rise And Fall of InTERnATIONAL LAW 1870-1960, at 413-509 (2001).

13 See Filártiga v. Peña-Irala, 630 F.2d 876 (2d Cir. 1980).

${ }^{14}$ U.S. CONST. Art. III, $\$ 2$, cl. 1.

15 See, e.g., Curtis A. Bradley \& Jack L. Goldsmith, Customary International Law as Federal Common Law: A Critique of the Modern Position, 110 HARV. L. REV. 815 (1997).

${ }^{16}$ Louis Henkin, International Law as Law in the United States, 82 MICH. L. REV. 1555, 1561 (1984).

${ }^{17}$ Id. at $1561-62$.

${ }^{18}$ Sosa v. Alvarez-Machain, 542 U.S. 692, 725-26 (2004).

${ }^{19}$ Id. at 724 .

${ }^{20}$ Kiobel v. Royal Dutch Petroleum Co., 133 S.Ct. 1659, 1669 (2013).

${ }^{21} \mathrm{Id}$.
} 
Consistent with his previous skepticism of international law's authority, ${ }^{22}$ Roberts was careful to describe the presumption against extraterritoriality as a separation-of-powers principle, in contrast to how lawyers supporting the defendant corporations had relied on international law arguments. ${ }^{23}$ Adjudication of extraterritorial matters affects foreign affairs, he explained, and foreign policy is the prerogative of the political branches. ${ }^{24}$ Thus, to complete the syllogism, federal courts should not apply laws extraterritorially absent a clear statement from the Congress to the contrary. ${ }^{25}$

However, the majority opinion mischaracterized the presumption against extraterritoriality as purely a domestic separation-of-powers issue while overlooking its bases in international law. ${ }^{26}$ The very idea that states are sovereign within their territorial borders and should not normally interfere with conduct that occurs inside other states' territories is premised on at least a general, if not outdated, view of international legal order. That view suggests that we live in a world of states organized around the principle of exclusive state sovereignty and a default norm of noninterference among states. These ideas are principles of international law that began to take hold in the eighteenth and nineteenth centuries. ${ }^{27}$ They have never been absolute principles, and their force is waning in a twenty-first-century world that requires regulation of increasingly complicated transnational commerce and interaction. They are, nevertheless, principles that reflect a particular set of aspirations about how the international realm should be ordered. Their influence might be taken for granted today, even by those who disagree with them, but, if so, that development is extraordinary. For most of human history, the international order was structured hierarchically among empires, not states, and more powerful empires maintained prerogatives to interfere in the affairs of weaker groups. ${ }^{28}$

22 See, e.g., Medellín v. Texas, 552 U.S. 491, 506 (2008) (holding, in an opinion by Roberts, that decisions of the International Court of Justice do not have legal force in the United States absent legislation rendering them domestic law, despite the United States being a party to that Court's founding treaties).

${ }^{23}$ See, e.g., Supplemental Brief of Chevron Corp. et al. as Amici Curiae in Support of Respondents, Kiobel v. Royal Dutch Petroleum Co., 133 S.Ct. 1659 (2013) (No. 10-1491), available at http://www.losangelesemploy mentlawyer.com/International-Human-Rights/Chervron-Corp-Dole-Food-Co-Dow-Chem-FordGlaxosmithkline-and-P-G.pdf (arguing that the extraterritorial application of the ATS violates international law).

${ }^{24}$ Kiobel, 133 S.Ct. at 1664-65.

${ }^{25} \mathrm{Id}$. at 1665.

${ }^{26}$ See Gary B. Born, A Reappraisal of the Extraterritorial Reach of U.S. Law, 24 LAW \& POL'Y INT'L BUS. 1, 10-19 (1992) (discussing the presumption's origins in international law).

27 See, e.g., JOSEPH STORY, COMMENTARIES ON THE CONFLICT OF LAWS 19 (1834); EMER DE VATTEL, THE LAW OF NATIONS 75 (Béla Kapossy \& Richard Whatmore eds., Thomas Nugent trans., 2008) (1758). Some commentators argue that international law does not recognize a presumption against extraterritoriality. See David L. Sloss, Kiobel and Extraterritoriality: A Rule Without a Rationale, 28 MD. J. INT'L L. 241, 241-44 (2013). The argument relies on S.S. Lotus (Fr. v. Turk.), 1927 PCIJ (ser. A) No. 10, at 18-19, which adopted a permissive, rather than prohibitive, approach to default international norms and reasoned accordingly that states are generally free to exercise jurisdiction extraterritorially absent a specific prohibition. However, the 1927 case has been rightly criticized as "represent[ing] the high water mark of laissez-faire in international relations, and an era that has been significantly overtaken by other tendencies.” Arrest Warrant of 11 April 2000 (Dem. Rep. Congo v. Belg.), 2002 ICJ REP. 3, 78, para. 51 (Feb. 14) (Higgins, Kooijmans \& Buergenthal, JJ., joint sep. op.); see also id. at 43, para. 15 (Guillaume, J. \& Pres., sep. op.) (noting that "the adoption of the United Nations Charter proclaiming the sovereign equality of States, and the appearance on the international scene of new States, born of decolonization, have strengthened the territorial principle"). Moreover, even if S.S. Lotus applies, the case does not mark a clean break from the territorial principle in favor of extraterritoriality, given that it relied on the "effects" on Turkish territory of an alleged offense committed on the high seas in order to uphold Turkey's jurisdiction over the offender. See S.S. Lotus, supra, at 23. See generally CEDRIC RYNGAERT, JURISDICTION IN INTERNATIONAL LAW 30-31 (2008).

${ }^{28}$ See DAVid ARMitage, Foundations of MOdERn InTERnATIONAL THOUGHT 21 (2013). 
Roberts avoided the international law argument in Kiobel, but it is uncertain that, in the long run, the Kiobel holding will withstand scrutiny without recourse to international legal norms to explain it. The problem with the majority's proffered separation-of-powers rationale is that it merely assumes that it is possible for the courts to take a neutral position toward foreign policy when a case arises that concerns foreign affairs. But declining to adjudicate a case involving an international issue can affect foreign relations as much as hearing the case. ${ }^{29}$ No matter how the Court ruled, it would have altered the calculus of international human rights enforcement. Not only did the Court disregard this inevitability by claiming that it had issued a decision that neutrally deferred to the political branches regarding foreign policy, but, even more brazenly, it did so in a decision that directly contravened the wishes of the political branches, which had advocated a more flexible approach toward allowing human rights cases against foreign defendants in federal courts. ${ }^{30}$

The incongruity between the holding and stated rationale in Kiobel appears most clearly where Roberts tried to explain how the ATS does not apply extraterritorially even though, under Sosa, it still applies to piracy on the high seas. ${ }^{31}$ He attempted to distinguish piracy from other violations of international law outside U.S. borders by claiming that "[a]pplying U.S. law to pirates . . . carries less direct foreign policy consequences." 32 But the Court got its history of pirates wrong. Judicial involvement in piracy cases often stoked major foreign policy debates. ${ }^{33}$ For example, the Monroe administration took advantage of piracy cases during the Latin American wars of independence to punt to the federal courts any decision to recognize the revolutionary governments. In cases involving the capture of Iberian vessels by Americans aboard privateers commissioned by the revolutionary governments, the courts were left on their own to determine whether the commissions were valid or whether the Americans holding those commissions were pirates. ${ }^{34}$ Similarly, the judicial debate between Chief Justice John Marshall and Justice Joseph Story over whether slavers were pirate ships under international law, and thus subject to lawful search and condemnation, involved the courts in one of the most significant controversies ever in Anglo-American relations. ${ }^{35}$ It took Britain forty years to persuade the United States to treat slave trading as piracy under international law. ${ }^{36}$ In short, as strange as it might seem today, piracy cases were controversial in American history precisely because they were fraught with foreign policy implications.

A stronger way to reconcile the Sosa holding that the ATS applies to piracy and the Kiobel holding that the ATS does not generally apply extraterritorially is to recognize that, under international law, the principle against extraterritoriality historically limits sovereigns from acting within the boundaries of other sovereign states, including on pirate ships subject to flag jurisdiction, but does not limit sovereigns from acting against actors on the high seas who have

29 See Noah Feldman, When Judges Make Foreign Policy, N.Y. Times MAG., Sept. 28, 2008, at MM50.

30 Sloss, supra note 27 , at 247-50.

31 Sosa v. Alvarez-Machain, 542 U.S. 692, 724-25 (2004).

${ }^{32}$ Kiobel v. Royal Dutch Petroleum Co., 133 S.Ct. 1659, 1667 (2013).

33 See id. at 1672 (Breyer, J., concurring).

${ }^{34}$ See Kevin Arlyck, Plaintiffs v. Privateers: Litigation and Foreign Affairs in the Federal Courts, 1816-1822, 30 LAW \& HIST. REV. 245, 261, 273 (2012).

35 See The Antelope, 23 U.S. (10 Wheat.) 66, 120 (1825); United States v. La Jeune Eugenie, 26 F.Cas. 832 (C.C.D. Mass. 1822) (No. 15,551).

36 See Hugh G. Soulsby, The Right of SeArCH AND the SlaVe Trade in ANGLO-American RElaTIONS, 1814-1862 (1933). 
forfeited any state allegiance. ${ }^{37}$ Both actions affect foreign policy, but modern international law has traditionally limited only the former. Thus, in the long run, Kiobel might come to be read not as a separation-of-powers decision but rather as a decision about a particular view of international legal order. The holding in Kiobel might outlive its stated rationale.

Kiobel therefore might ultimately contribute to a return to a stronger foundation of customary international law in U.S. courts. The decision underscores that the United States exists within an international system and sometimes must consider that system's norms in order to organize its own rule of law. Even though the particular international legal principles on which Kiobel relied are contentious and have struck observers as archaic in their emphasis on territorial line drawing and exclusive sovereignty, ${ }^{38}$ Kiobel nevertheless demonstrates the appropriateness, if not occasional necessity, of reasoning from principles of international legal order to resolve disputes in U.S. courts. This observation is no more controversial than the Declaration of Independence, which was premised on the existence of an international order of independent states with rights "to levy War, conclude Peace, contract Alliances, establish Commerce" and the claim that a sovereign people had the right to form an independent state and acquire these rights. ${ }^{39}$ The Declaration's second paragraph about individuals' "unalienable Rights" has come to dominate our memory of the document, but it was originally a document of international law directed toward the international community and aimed at achieving for the United States a recognized position, in its first paragraph's words, "among the powers of the earth." ${ }^{40}$ The perceived authority of "the People" to enact a constitutional regime and to enjoy sovereign equality rests on international legal principles. In Kiobel, the Court still does not provide an explicit theory for how such principles have force in the United States, but their common-sense application by nine justices suggests that they do.

\section{Conclusion}

Even if litigation in U.S. courts over human rights abuses abroad were to come to a halt after Kiobel, the decision need not be seen as hostile to international law or even human rights. After all, human rights litigation under the ATS has been largely symbolic and has rarely led to liability. If Kiobel becomes understood as an instance of reasoning from international legal principles, then it might ultimately contribute to a more robust notion of the role of customary international law in U.S. courts. Those who believe international legal norms can play a constructive role may have to abandon ambitious aspirations regarding human rights litigation in exchange for broader recognition of the validity of reasoning from international legal norms.

\footnotetext{
37 See R. v. Dawson, 13 How. St. Tr. 451, 455 (High Ct. Adm. 1696) (universal jurisdiction over piracy). Historically, the Supreme Court has hesitated to apply U.S. laws to pirates subject to the jurisdiction of a country whose flag their ship flew, but it was less hesitant where pirates flew no flag, save the Jolly Roger. Compare United States v. Palmer, 16 U.S. (3 Wheat.) 610, 643 (1818) (declining to apply piracy statute to piratical acts "on board of a ship or vessel belonging exclusively to subjects of any foreign state"), with United States v. Klintock, 18 U.S. (5 Wheat.) 144, 152 (1820) (applying same piracy statute to piratical acts committed "on board of a vessel not at the time belonging to the subjects of any foreign power").

38 See, in this Agora, Zachary D. Clopton, Kiobel and the Law of Nations; Ralph G. Steinhardt, Kiobel and the Weakening of Precedent: A Long Walk for a Short Drink.

39 THE DECLARATION OF INDEPENDENCE (U.S. 1776).

${ }^{40}$ Id.; see DAVid ARMitage, The DeClaration Of IndePENDENCE: A Global History 25-62 (2007).
} 
This outcome, ultimately, would be a muted victory for international legal norms in U.S. courts. 